\title{
O NÃO-SENSO EM ANA CRISTINA CESAR E MARCOS SISCAR
}

\section{THE NONSENSE IN ANA CRISTINA CESAR AND MARCOS SISCAR}

\author{
Annita Costa MALUFE ${ }^{70}$
}

\begin{abstract}
RESUMO: As poéticas de Ana Cristina Cesar e de Marcos Siscar encontram-se em um importante ponto comum: o trabalho com o nãosenso. Trata-se de um gesto arriscado de escrita, pouco frequente dentre as poéticas atuais, que aproximaria seus projetos das propostas das vanguardas artísticas do século XX. Para além de identificar ou valorar este gesto, o artigo analisa a composição de seus poemas levando-se em conta este trabalho com o não-senso enquanto modo de produzir um abalo na linguagem e, com isto, uma vertigem poética.
\end{abstract}

PALAVRAS-CHAVE: Poesia brasileira contemporânea; Ana Cristina Cesar; Marcos Siscar; Não-senso; Sentido.

\begin{abstract}
The poetics of Ana Cristina Cesar and Marcos Siscar have an important common point: their work with the non-sense. This is a risky act of writing, uncommon among current poetry, which would aproximate their projects to the artistic vanguards proposals of the twentieth century. More than identifying and valuing this gesture, the article analyzes the composition of their poems, taking into account this work with non-sense as a way to produce a language concussion and a poetic vertigo.
\end{abstract}

KEYWORDS: Brazilian contemporary poetry; Ana Cristina Cesar; Marcos Siscar; Nonsense; Sense.

Poderia ser apenas uma escolha ao acaso, pinçar dois poetas significativos no cenário da poesia contemporânea brasileira. Entretanto, algo guiou este breve diálogo que traço aqui entre Ana Cristina Cesar e Marcos Siscar. Dois poetas que destoam de um certo modo mais acostumado de ser da linguagem e mesmo da poesia. Ana Cristina Cesar e Marcos Siscar teriam em comum o fato de trabalharem com a linguagem de maneira a fazê-la sair um pouco dos trilhos, descarrilar. E ter em vista este movimento não implica pensar em termos históricos ou de época. Embora o contexto sempre esteja em jogo, penso mais em termos geológicos mesmo ou, ainda, topológicos: hoje,

\footnotetext{
${ }^{70}$ Pós-doutoranda (bolsista FAPESP). Pontifícia Universidade Católica de São Paulo (PUC-SP) - São Paulo - SP - Brasil - annitacostamalufe@ gmail.com
} 
olhando para essas poéticas, é possível notar um certo tremor, uma certa força disruptiva, que se destaca de questões de época. É apenas esta intuição que operou em minha escolha.

Não gostaria, portanto, de pressupor uma leitura linear da história, que veria em uma poética uma espécie de superação da anterior ou um passo além - ou, ainda, veria passos atrás em certas propostas atuais por não serem de vanguarda ou por obedecerem ou não a ideologias vigentes etc. Ao contrário, se o contexto conta é porque ele está inevitavelmente presente, e atuante, tanto na produção quanto na recepção da poesia. $\mathrm{E}$ pode-se dizer ainda que, de tanto estar presente, o contexto não é um só, mas ele é coexistência de múltiplos contextos, sempre atuantes, sobrepostos, contaminando quem escreve e quem lê.

Então se delimitarmos um terreno, este da poesia dita contemporânea, dos anos 1970 para cá, e ainda um outro, o da produção brasileira, haveria diversos pontos notáveis no nosso relevo. E me proponho a explorar dois deles, a partir da sensação de que algo sobressai neles, independentemente de um juízo que diria se são mais ou se são menos contemporâneos, avançados, do que outros autores. Algo sobressai nas propostas de Ana Cristina Cesar e de Marcos Siscar que, como dizia, tem a ver com fazer a linguagem sair do eixo, ser abalada em suas bases, como se avançasse por lugares mais incertos e, talvez, proliferantes. É neste sentido que elegi um ponto mais forte, que ligaria a poética dos dois e que se refere a uma questão importante a ser considerada no nosso cenário atual da poesia, talvez não só brasileira: o trabalho com o não-senso, ou o não-sentido, ou ainda, o trabalho com o silêncio - entendido de um modo específico que vou tentar explicar aqui.

Este ponto em comum também pode justificar uma outra questão: o fato de não haver uma ligação óbvia ou evidente entre as obras de Ana Cristina Cesar e Marcos Siscar. Trata-se de uma ligação até bastante disparatada, digamos. Pois há mais diferenças do que semelhanças entre os dois. Ana Cristina apareceu no cenário da nossa poesia em meados da década de 1970, no Rio de Janeiro, ligada aos poetas ditos "marginais", à poesia de mimeógrafo. Teve vida curta, morreu aos 31 anos em 1983, depois de lançar seu único livro de poemas por uma grande editora, o conhecido A teus pés. Foi uma poeta bem desta transição, entre as décadas de 1970 e 80 , que nem chegou a ver o fim da ditadura militar no Brasil. 
Já Marcos Siscar - poeta do interior de São Paulo, nascido em 1964 - publica seu primeiro livro em 1999, ou seja, quase na virada do século XX. É nos anos 2000 que sua poesia começa a ganhar mais força e a ficar mais conhecida. O seu livro mais conhecido, e que reúne três livros anteriores seus, é o Metade da arte. E foi publicado em 2003. Depois, Siscar lançou mais dois livros de poesia (o último no ano passado) e, hoje, é um poeta que está em plena atividade e que possui ainda intensa atuação no meio universitário da crítica literária. Sua poesia surge, assim, numa época bem diferente daquela de Ana Cristina, com o Brasil em pleno processo democrático, neoliberal e, ainda, em um mundo pós-queda do muro de Berlim, já tomado pelas novas mídias, invadido pela Internet, pela intensificação da cultura de mercado, por toda essa aceleração que talvez fosse impensável na década de 70 .

Então, para começar, a época de cada um é bem diversa, 20 anos separam suas produções; e quando Ana Cristina morreu, Siscar ainda estava longe de publicar seu primeiro poema. Por outro lado, isto tampouco desemboca numa relação de filiação. Marcos Siscar, que veio depois, não se insere em uma linha ou escola que poderíamos associar como vinda de Ana Cristina. Na realidade, Marcos Siscar não se insere em escola alguma, como talvez seja o caso da maioria dos poetas que escrevem a partir da década de 80. E mesmo Ana Cristina não fez escola, e não se inseriu em escola alguma. No entanto, há quem diga que a poesia marginal dos anos 70 foi um dos últimos movimentos no cenário da poesia - neste sentido de um grupo organizado e com uma proposta coletiva mais clara - e Ana Cristina fez parte deste grupo, no início. Mas sua poesia foi logo se distanciando do senso comum de sua geração e criando um estilo próprio, bastante diferenciado.

Mesmo se considerássemos um estilo "Ana C." ou "marginal”, este tampouco seria o que mais se aproximaria da escrita de Marcos Siscar. São propostas bem diversas, bem singulares, em termos estilísticos. Mesmo as referências poéticas e literárias de cada um são bastante diferentes. Ana C. fez seu Master em tradução na Inglaterra, estudava Katherine Mansfield, Sylvia Plath, Emily Dickinson, Walt Whitman, gostava da literatura beat, que era moda na sua geração. Era mais próxima da literatura de língua inglesa. Já Siscar está mais ligado a referências francesas; também é tradutor, mas do francês, fez o mestrado sobre a poesia de Tristan Corbière e seu doutorado na França, com o poeta Michel Déguy, sobre a retórica do filósofo Jacques 
Derrida. Suas referências são mais próximas da poesia francesa, Baudelaire, Rimbaud, Mallarmé, Valéry e Samuel Beckett, por exemplo.

Porém, a despeito das grandes distâncias, há referências comuns aos dois. Como a poesia ou o cânone moderno mais universal, a leitura de Baudelaire, Mallarmé e de poetas modernos em ambos; e, ligada a isto, a relação forte com o modernismo brasileiro, em especial Manuel Bandeira e Carlos Drummond de Andrade. Há ainda, nos dois, uma proximidade com a filosofia mais contemporânea, naquilo que a filosofia serve de aliada para se pensar a literatura. Ana C. conhecia alguns escritos de Derrida, filósofo que Siscar estuda, e lia outros filósofos franceses, como Gilles Deleuze, Michel Foucault, Roland Barthes, pensadores do século XX que surgiram depois da onda estruturalista (de Lévi-Strauss ou Saussure), já questionando o estruturalismo. E Ana C. se interessava por eles e por pensar o estatuto da poesia e da linguagem e escrevia ensaios sobre isto, assim como Siscar. Encontramos em ambos, assim, uma atividade reflexiva sobre a poesia, que acompanha a escrita. Ou ainda: um fazer poético que se dá nessas duas frentes: a teórica, na reflexão sobre poesia, e a prática, na escrita dos poemas. Este é um traço que podemos encontrar nos dois poetas, sendo que em ambos esta reflexão se dá a partir de estudos antenados com o pensamento filosófico contemporâneo, pós-estruturalista, na direção de buscar uma atualidade de pensamento sobre a poesia.

Há pontos em comum que podemos encontrar entre Siscar e Ana Cristina, mas digamos que não há nada muito evidente ou direto, que os ligaria obrigatoriamente. A conexão que traço entre suas poéticas deu-se em minha leitura a partir do contato que travei, inicialmente, com a poesia da Ana Cristina Cesar. ${ }^{71} \mathrm{E}, \log$ a aí, a intuição de que, em seu projeto poético, havia um forte questionamento da linguagem e do que "é" ou o que "pode ser", ou vir a ser, a poesia. Talvez esta seja uma atitude característica de um determinado modo de se enxergar a poesia desde o século XX: este de que a poesia é algo que leva a língua a um certo limite, que a põe em questão - ou até, como diz Octavio Paz (1974), a poesia que é crítica por definição, sendo ela mesma uma crítica e uma autocrítica da própria poesia. Pode-se dizer que Ana C. se destaca no grosso de seus colegas de geração justamente neste sentido de questionar radicalmente a própria

\footnotetext{
${ }^{71}$ Em meu mestrado, Territórios dispersos: a poética de Ana Cristina Cesar (Annablume/ Fapesp, 2006) e, em seguida, em meu doutorado, Poéticas da imanência: Ana Cristina Cesar e Marcos Siscar (Ed.7Letras/ Fapesp, 2011), no qual discuto mais detalhadamente as ideias aqui desenvolvidas.
} 
natureza da linguagem, colocando em jogo na poesia o estatuto mesmo do sentido. É este o gesto que salta em sua proposta, numa poesia que se fará na beirada do nãosenso, na ruptura com a comunicabilidade e a significação geral das palavras.

Octavio Paz, em Los hijos del limo, diz que a tradição moderna é justamente a tradição da ruptura. É a repetição do gesto de interromper o que vinha para recomeçar o novo; e que este seria um gesto moderno, vindo desde o romantismo, que encontrará seu auge nas vanguardas artísticas do início do século XX. Digamos, portanto, que há nas propostas de Ana C. e Siscar uma atitude de escrita que ecoa esta ruptura, trabalhando arriscadamente com as palavras, uma vez que as levam no limite da significação portanto, na fronteira de seu próprio colapso. A experiência que talvez emerja daí, na leitura, seria uma espécie de ausência de chão mais firme, de vertigem, ou mudança de contornos fixos. Tal vertigem pode ser um pretexto para aproximarmos poetas tão distintos e é ela que tenho em vista ao enfocar a questão do não-senso em suas poéticas.

Ana Cristina Cesar (1999b, p.267) dizia assim: "Você pode ter lido um ou dois [poetas] e já sacar o que é poesia: que a poesia é um tipo de loucura qualquer. É uma linguagem que te pira um pouco, que meio te tira do eixo". Então a experiência de ler um poema pode ser isto: adentrar em um lugar meio inesperado, que te tira do eixo, que te desequilibra, abala tuas sensações, tuas convicções do real. O caminho escolhido por Ana Cristina para fazer isto é curioso, porque ela não abre mão completamente da dita "realidade", ela não abre mão do registro cotidiano, das palavras do dia-a-dia, das vivências banais, dos clichês. Ela não só não abre mão, como escolhe partir de dentro desse universo comum, corriqueiro, para cavar este abismo, esta vertigem. O caminho que ela escolhe não é mais o da ruptura radical, como era nas vanguardas do início do século XX: ela não opta por "chocar", rompendo completamente com a significação das palavras, como nos poemas futuristas ou dadaístas, como também não opta por uma poesia hermética ou extremamente técnica ou formalista, como no caso das correntes mais racionalistas, o abstracionismo, mais tarde o construtivismo, nas artes, e o concretismo, na poesia. Embora haja bastante erudição em seus textos, é curioso que os sentidos não dependem, para acontecerem, de uma chave de leitura que a referência erudita poderia nos fornecer. Seu projeto poético era o de sugerir uma experiência de leitura apartada de referenciais da memória. Espécie de leitura "desmemoriada" - ainda que ela escrevesse, sim, a partir de diversas referências literárias e pessoais. 
O caminho que ela escolhe é parecido com o tom geral de sua geração, que partia da proximidade poesia e vida, valorizando o registro do cotidiano na poesia, a opção por um vocabulário coloquial e muito oralizado, vocalizado, muito colado na fala, na vivência cotidiana das palavras. Ela opta, ainda, pela escrita próxima a gêneros íntimos, como a de cartas e diários, e pela voz sempre em primeira pessoa. Este é um traço de sua época também. Como aponta Viviana Bosi (2010), o projeto da poesia dita marginal dialoga com o projeto contracultural das vanguardas da segunda geração, por exemplo o nosso neoconcretismo, Lygia Clark, Hélio Oiticica e mesmo Ferreira Gullar (em seus escritos críticos); projeto que se colocava enquanto antiarte no sentido do desfazimento dos limites entre arte e vida, expandindo um campo no outro e acabando com os limites da página do poema - assim como nas artes plásticas acabava-se com o limite da moldura. Ana C. está nesse contexto, mas o que será curioso é a distância que sua poesia tomará da dos outros poetas de sua geração, indo mais longe no questionamento dos limites não só da poesia, mas da própria linguagem. E tal distância acontece principalmente pela quebra na comunicabilidade do poema; aposta que Ana C. acaba fazendo praticamente sozinha no cenário de sua geração.

É esta quebra da comunicabilidade que ecoa mais radicalmente o gesto de ruptura das vanguardas. Em alguns momentos, talvez possamos encontrar algo neste sentido em Waly Salomão, mas de modo não generalizado em seu projeto poético mais amplo. Isto é, embora em Waly haja experimentações que arriscam arrancar o chão do significado e da comunicação, muitos de seus poemas se apoiam nos significados por eles construídos. Ainda que esta significação venha carregada por múltiplos desvios ao longo do poema e por uma linguagem excessiva, transbordante, ela é traço marcadamente constitutivo do poema. Isto é, o poema "diz", "quer dizer" algo, e este algo é fundamental para o sentido de fato acontecer ao se ler muitos dos textos de Waly Salomão.

É diferente do que ocorre em Ana Cristina. Como também daquilo que ocorre em Marcos Siscar - que, assim como ela, me parece dos poucos autores, dentre a sua geração, aquela dos anos 1990 e 2000, que arrisca a linguagem nesta beirada do sentido com o não-sentido. Se há em ambos um trabalho com o não-senso e com a vertigem que a leitura pode extrair disto, em ambos, isto não implica em fazer uma poesia formalista, nem hermética ou erudita, que demande decifração, tampouco uma poesia que seja non- 
sense por inteiro, abrindo mão completamente dos significados das palavras, como acontecia, por exemplo, nos poemas dadaístas ou mesmo surrealistas, no início do século XX. O que gostaria que notássemos nesses poemas de Siscar e de Ana C. é como eles operam uma espécie de ataque aos significados das palavras e à significação mais geral do poema; como neles temos um desfazimento de significações, uma desmontagem da função comunicativa da linguagem que opera discretamente. Uma quebra sutil se infiltra nas palavras a partir de pontos em branco, não nomeáveis, que operam conjuntamente à doação de sentido. Esta quebra é tão discreta que, muitas vezes, podemos até acreditar que, por trás de seus poemas, Ana C. e Siscar contam-nos histórias, de fato, guardam, verdadeiramente, segredos e enigmas.

No caso de Ana Cristina, isto se dá a partir do cenário íntimo, em textos que parecem derivados da forma-diário ou da forma-carta. Ela brinca com a questão do segredo íntimo, com a violação da correspondência ou o diário alheio. Mas curiosamente esta violação não descobre nada, ela é uma falsa violação:

\author{
21 DE FEVEREIRO \\ Não quero mais a fúria da verdade. Entro na sapataria popular. \\ Chove por detrás. Gatos amarelos circulando no fundo. \\ Abomino Baudelaire querido, mas procuro na vitrina um \\ modelo brutal. Fica boazinha, dor; sábia como deve ser, não tão \\ generosa, não. Recebe o afeto que se encerra no meu peito. Me \\ calço decidida onde os gatos fazem que me amam, juvenis, \\ reais. Antes eu era 36, gata borralheira, pé ante pé, pequeno \\ polegar, pagar na caixa, receber na frente. Minha dor. Me dá a \\ mão. Vem por aqui, longe deles. Escuta, querida, escuta. A \\ marcha desta noite. Se debruça sobre os anos neste pulso. Belo \\ belo. Tenho tudo que fere. As alemãs marchando que nem \\ homem. As cenas mais belas do romance o autor não soube \\ comentar. Não me deixa agora, fera. (1999a, p.106).
}

Este é um poema de Cenas de abril (seu primeiro livro que foi lançado em 1979 em edição caseira e depois retomado em A teus pés), de uma série de poemas que trazem essas datas no título, como ele, como se fossem páginas arrancadas de diários. Na última série, intitulada "A teus pés" mesmo, publicada em 1982, esses diários estão mais recortados, mais misturados com os poemas. Então mantém-se o tom de diário e de carta mas tem-se textos mais fragmentários ainda e com outras formas - muitos deles também são poemas em prosa, ou são um misto de poema com poema em prosa, como por exemplo, "Duas antigas", poema em duas partes: 
I.

Vamos fazer alguma coisa:

escreva cartas doces e azedas

Abre a boca, deusa

Aquela solenidade destransando leve

Linhas cruzando: as mulheres gostam

de provocação

Saboreando o privilégio

Seu livro solta as folhas

Aí então ela percebeu que seu olho corria veloz pelo museu e só parava em três, desprezando como uma ignorante os outros grandes. E ficou feliz e muito certa com a volúpia da sua ignorância. Só e sempre procura essas frases soltas no seu livro que conta história que não pode ser contada.

Só tem caprichos.

É mais e mais diária

- e não se perde no meio de tanta e tamanha

companhia.

II.

Eu também, não resisto. Dans mon île, vendo a barca e as gaivotinhas passarem. Sua resposta vem de barca e passa por aqui, muito rara. Quando tenho insônia me lembro sempre de uma gaffe e de um anúncio do museu: "to see all these works together is an experience not to be missed". E eu nem nada. Fiz misérias nos caminhos do conhecer. Mas hoje estou doente de tanta estupidez porque espero ardentemente que alguma coisa... divina aconteça. F for fake. Os horóscopos também erram.

Me escreve mais, manda um postal do azul (eu não me espanto).

O lugar do passado? Na próxima te digo quem são os 3 , mas os outros grandes... eu resisto.

Não fica aborrecida: beijo político nos lábios de cada amor que tenho. (1999a, p.56-57).

Porém, já houve quem avaliasse a poesia de Ana C. como sendo absolutamente non-sense, como se ela lançasse mão do recurso da escrita automática surrealista, escrevendo ao sabor do acaso e sem construção ou projeto algum. Porque o efeito que ela consegue é mesmo este, o de um texto espontâneo, e conduzido por um fluxo inconsciente. Mas a partir dos textos teóricos dela e, posteriormente, com nosso acesso aos rascunhos da poeta, sabemos o quanto sua escrita era trabalhada, o quanto ela prezava a construção dos poemas, reescrevendo-os várias vezes, rasurando, jogando 
muita coisa fora e trabalhando bastante em cima dos rascunhos. Havia, portanto, um projeto de escrita por trás, uma pesquisa, e não um gesto aleatório, espontâneo.

Esta atmosfera de segredo que sentimos nestes poemas é a atmosfera presente em toda a sua obra. Como vemos aqui, as informações não estão muito claras, elas vêm meio nubladas, não conseguimos saber exatamente a que ela se refere. Ao mesmo tempo, o tom é absolutamente íntimo, próximo, as palavras são cotidianas. É como se houvesse uma história correndo por trás, mas que estaria como que pressuposta pelo interlocutor do poema. $\mathrm{O}$ poema fala a alguém e parece que este alguém sabe do que ele está falando, de modo que aquele que escreve, o remetente, nem precisa entrar em detalhes e nomear tudo. Ele fala com meias palavras, ele salta de um assunto para o outro.

Esses saltos são um recurso típico do estilo de Ana Cristina. Trata-se de uma escrita feita de fragmentos justapostos, recortes, retalhos. Alguns teóricos já disseram isto, como por exemplo Ítalo Moriconi (1996) ou Flora Süssekind (1995), referindo-se à presença de trechos de outros autores nos poemas de Ana C., de modo que ela faria como que uma colcha de retalhos, um patchwork de outros autores. Flora destacou, em seu ensaio Até segunda ordem não me risque nada, por exemplo, a "poesia-em-vozes" de Ana C., isto é, criação de uma voz própria que se faz a partir do registro, recorte e incorporação de múltiplas vozes de outros. Ana Cristina captava falas de outros autores como captava falas de passantes na rua, de conversas com seus amigos, ou de cartas suas, de cadernos e anotações seus ou poemas anteriores de sua autoria... Assim o material bibliográfico, literário, que ela utiliza, ou seja, as intertextualidades que percorrem seus poemas, compõem sua voz do mesmo modo que o material cotidiano. Ela trabalhava com um material vocal múltiplo que ela recortava e rearticulava, reutilizava. Eram as pequenas peças para montar seus poemas.

Podemos lembrar que este é um procedimento típico das vanguardas artísticas, algo que talvez tenha começado com os dadaístas, que propuseram a colagem como método de composição literário e também artístico. ${ }^{72}$ Em seguida, Appolinaire - poeta que inspirou bastante os surrealistas e que se dizia cubista - e também T. S. Eliot e Pound vão compor seus poemas a partir desse procedimento de recorte e justaposição de

\footnotetext{
${ }^{72}$ É exemplar neste sentido o poema-receita de Tristan Tzara "Para se fazer um poema dadaísta" (TZARA, 1996, p.228-229), em que ele ensina que se recorte uma notícia de jornal, para depois se sortear e colar as palavras ao acaso.
} 
fragmentos. Fossem fragmentos de cenas, como flashes recolhidos na cidade, fossem trechos de outros autores, a ideia era compor o poema rearranjando pedaços, e deixando este aspecto de composição quebrada, lancetada, um todo quebrado, que já não pode ser unificado, que não é harmônico, que se mostra enquanto montagem, junção de disparates.

Assim, este é o projeto que ecoa nos poemas de Ana Cristina. E o corte-colagem é um dos seus principais procedimentos de escrita. Por exemplo no primeiro poema citado, "21 de fevereiro", há trechos de um poema de Baudelaire (1964, p.200-202), "Recolhimento", de Les fleurs du mal, em "fica boazinha, dor; sábia como deve ser" e "Minha dor. Me dá a mão. Vem por aqui, longe deles. Escuta, querida, escuta. A marcha desta noite". São trechos que ela arranca do poema de Baudelaire e incorpora em seu texto, citados quase que literalmente. ${ }^{73}$ Neste mesmo poema, tem-se ainda a referência a Manuel Bandeira, em "Belo belo" - título do livro e do poema de Bandeira. Aqui, o "tenho tudo quanto quero" do verso de Bandeira vira "tenho tudo que fere" em Ana.

Vemos que ela toma esses pedaços como fragmentos independentes, ela rearranja-os com outros fragmentos de textos seus - e já não importa tanto se era Baudelaire ou Bandeira que estavam ali, pois eles ganham novos sentidos no texto que ela compõe. Diferentemente do que ocorre em outros poetas, por exemplo Ezra Pound, em Ana C. o leitor não precisa necessariamente conhecer os textos de Bandeira ou de Baudelaire para que seu poema faça sentido. Ela mesma defendia este tipo de leitura, que fosse desatrelada das referências - fossem elas eruditas, fossem de sua vida pessoal ou da vida pessoal de qualquer outro autor. Importava, para ela, que a leitura fosse um campo livre em que novas ligações pudessem ser disparadas. "Ler é meio puxar fios, e não decifrar”, dizia (1999b, p.264). Ler é puxar seus próprios fios, suas próprias malhas de relação, é ser tomado por malhas inesperadas, que se fazem antes mesmo de qualquer decifração. A vertigem relaciona-se com este tipo de leitura, portanto, que é uma experiência de puxar seus próprios fios e cair nas malhas do poema, sem garantias.

Ao contrário desta leitura que "puxa fios", aquela que decifra seria a que faz do poema um objeto desmontável, buscando as fontes de cada uma de suas peças, visando preencher todas as lacunas, as entrelinhas. Nomeando as fontes, achando as

\footnotetext{
${ }^{73}$ Como nos versos: "Sois sage, ô ma Douleur, et tiens-toi plus tranquille."; "Ma Douleur, donne-moi la main; viens par ici,/Loin d'eux.[...]" e "Entends, ma chère, entends la douce Nuit qui marche.".
} 
significações, as supostas mensagens, para que nada fique muito indeterminado, vagando solto por aí. Com este tipo de leitura-decifração de entrelinhas, foge-se da possibilidade do efeito de vertigem - que é uma vertigem da não-nomeação e justamente da falta de chão ou da falta de forma. A memória, as referências, os pontos de origem são solos supostamente firmes, que nos asseguram a explicação, a função, o lugar ao poema. Ao mesmo tempo, há a ilusão do desvendamento, pois de algum modo, quando os pedaços de Bandeira ou Baudelaire, ou Walt Whitman etc., são recortados e incorporados no poema de Ana C., eles já se tornaram outra coisa, já ganharam outras forças e outras formas. De modo que descobrir de onde as peças foram retiradas é apenas aparentemente um desvendamento. O mesmo pode ser dito acerca das experiências pessoais da autora. Os fatos vividos, ao serem recortados e remodelados no poema, já se tornam outra coisa, não são mais fatos meramente pessoais: "Se você conseguir contar a tua história pessoal e virar literatura, já não é mais a tua história pessoal, já mudou" (1999b, p.262), diz Ana Cristina.

Notemos ainda que, para além da colagem de trechos vindos de outros lugares trechos de textos seus ou de textos de outros, trechos de conversas etc. -, o procedimento de corte aparece em Ana C., ainda, para interromper, quebrar a fluência da oração. Isto é, criar um buraco, um vazio, no meio dela. Criar aquilo que ela chamará de não-dito. O poema citado "Duas antigas" é bem exemplar no que se refere à criação de não-ditos, pois ele é cheio de interrupções e de supostos enigmas. É como se ela suprimisse substantivos, nomes, verbos ou conectivos que poderiam deixar os significados do poema claros e distintos. Desde o título, temos uma supressão - duas antigas o quê? - e, em seguida os "três" e os "outros grandes" que aparecem e que não sabemos o que são. Três quadros, talvez? Na parte II ela até brinca: "na próxima te digo quem são os 3, mas os outros grandes... eu resisto."

O leitor fica com uma atmosfera de segredo, e ao mesmo tempo, de tom íntimo entre amigos ou entre amantes, acentuado pelo fato de que o poema tem o tom de uma carta. Assim, esta remissão a objetos e fatos que não estão explícitos, que são brevemente apenas sugeridos, constrói a impressão de que o interlocutor sabe do que o remetente está falando. No entanto, como vemos aqui, o assunto é um tanto banal. Não há nada de muito extraordinário nele, pelo contrário. Trata-se de questões íntimas, cenas do cotidiano comum que são desmontadas, desarticuladas e esburacadas pelos cortes. 
Qual seria a graça de restituir essas peças que foram retiradas, buscando completar entrelinhas?

Para Ana C., o não-dito é diferente da entrelinha. Ele remete a esta leitura do “puxar seus próprios fios”, enquanto que a entrelinha pertence à leitura-decifração. É possível encarar-se os vazios, os lapsos de um poema como sendo entrelinhas, a serem decifradas, ou como sendo não-ditos. E o não-dito é um silêncio que permanece enquanto silêncio, é um lapso que não remete a nada. Ele está aí para ser vivenciado enquanto silêncio, lapso sem solução possível no terreno da linguagem e da significação. Ela considerava que seu livro A Teus Pés: “conta com alguma coisa que não foi dita [...] mas enquanto questão literária. Na literatura sempre haverá alguma coisa que escapa" (CESAR, 1999b, p.260).

Minha sugestão é a de que os sentidos dos poemas de Ana Cristina dependem de que encaremos esses lapsos como não-ditos, e não como entrelinhas. Lapsos enquanto pontos de silêncio irredutíveis à nomeação. Ou seja, que vivenciemos este corte enquanto corte, de fato: rupturas no chão da significação. Elemento que, a partir de uma formulação do filósofo Gilles Deleuze, opto por chamar de não-senso. Vale remarcar aqui que, em Deleuze, como vê-se especialmente em Lógica do sentido ${ }^{74}$ sentido e nãosentido dão-se conjuntamente, ou seja, não estão em oposição. O não-senso é antes o marco zero do sentido, a possibilidade mesma da criação de sentidos renovados. Isto porque o sentido é, por si, sempre criação de sentidos - e não desvendamento ou escavação. É preciso que sejamos forçados, diante de um corte, um lapso, a criar sentidos. O sentido, para Deleuze, é sempre uma emergência, um efeito que se dá em tempo real e a cada vez. Não há sentidos preexistentes, jamais: é da natureza do sentido ser irrupção, estreia. E isto não apenas no poema, na literatura; embora aí tenhamos esta sina do sentido expressando-se de modo muito mais evidente. De modo que desvendar as histórias banais que estão por trás dos poemas de Ana C., as fontes dos trechos retirados de outros autores, não nos aproximaria de uma suposta significação mais verdadeira do poema. No máximo, descobrem-se fontes pessoais ou então, como vimos

\footnotetext{
${ }^{74} \mathrm{O}$ conceito de sentido enquanto efeito incorporal dando-se nos corpos, enquanto uma força dando-se na fronteira entre os corpos e a linguagem, é trabalhado por Deleuze desde Diferença e repetição (1968) e, mais especificamente, em Lógica do sentido (1969). No entanto, ele permeia todo seu pensamento filosófico. Não teríamos como desenvolver o conceito aqui, apenas saliento que é desta concepção que parte minha leitura. O importante, para o momento, é retermos esta emancipação do sentido das dimensões puramente linguísticas - com o que sentido e significado tornam-se instâncias de naturezas completamente distintas.
} 
nos poemas de Baudelaire e Bandeira aproveitados por Ana C., é-se remetido a outros poemas que possuem seus universos também e que não necessariamente esclarecem ou desvendam melhor o poema que deles se apropriou.

Isto porque os poemas de Ana Cristina encarnam uma separação mais nítida entre significado e sentido do que grande parte de nossa poesia recente, de sentidos ainda bastante apegados à significação. Em Ana C., os sentidos do poema não coincidem com suas significações. Os sentidos vão muito além das significações, muito além do isto quer dizer aquilo e de uma possível paráfrase do poema. Tal característica, certamente, poderia ser atribuída à poesia em geral (e mesmo à linguagem em geral, se partirmos do conceito de sentido tal como Deleuze o formula). Contudo, a sugestão é a de que a poesia de Ana C. pertence a um grupo de poéticas em que este caráter fica mais explícito. Seu poema não pode ser resumido em uma ideia central, um conceito ou uma mensagem que aglutinaria os elementos a seu redor. Não há o que o poema "quer dizer" - senão ficaríamos com histórias pequenas, banais, apenas.

No lugar de um conteúdo ocultado, o que se tem é a forma do segredo tornada sensível. O poema encarna o contorno do segredo. Um contorno vazio. Ana C., em um poema publicado postumamente, fala do inconfessável que deseja tomar forma, que vira forma no poema. E é o inconfessável então que vira forma, sintaxe, ritmo, é ele que se expressa, deixando de ser conteúdo para se tornar contorno:

\author{
discurso fluente como ato de amor \\ incompatível com a tirania \\ do segredo \\ como visitar o túmulo da pessoa \\ amada
}

a literatura como clé, forma cifrada de falar da paixão que não pode ser nomeada (como numa carta fluente e 'objetiva').

a chave, a origem da literatura

o 'inconfessável' toma forma, deseja tomar forma, vira forma

mas acontece que este é também o meu sintoma, 'não conseguir falar' = não ter posição marcada, idéias, opiniões, fala desvairada. Só de não-ditos ou de delicadezas se faz minha conversa, e para não ficar louca e inteiramente solta neste pântano, marco para mim o limite da paixão, e me tensiono na beira: tenho de meu (discurso) este resíduo. 
Não tenho idéias, só o contorno de uma sintaxe (= ritmo). (CESAR, 1999c, p.128).

Na poesia de Marcos Siscar podemos encontrar um movimento próximo a este. Se Ana C. defende o não-dito na superfície do poema, este que ela chama de "não-dito enquanto questão literária", Marcos Siscar vai trabalhar com o que "não se diz" - título de um de seus livros, publicado pela primeira vez em 1999 e posteriormente incluído em Metade da arte. Ao abordar sua poesia, tenho mais em vista esse livro e, particularmente, os poemas mais recentes aí incluídos: os que pertencem à última série que dá nome ao volume "Metade da arte", os de um pequeno livrinho anterior Tome seu café e saia, de 2002, e aos de Não se diz. ${ }^{75}$

Nesses poemas de Siscar, de Metade da arte, nota-se logo um predomínio do verbo dizer. E, ao mesmo tempo, a constância dessa atmosfera do "não se diz”. Há, por um lado, um transbordamento do dizer, as palavras numa espécie de excesso, de palavrório; e, por outro, a impressão de que há muita coisa não-dita ou muita coisa que “não se diz" sobrando por debaixo ou por entre as palavras. É curiosa esta sensação, de poemas tagarelas, que falam e falam, mas ao mesmo tempo parecem não dizer muita coisa, pois não estão sendo explícitos. É quase o "falar falar e não dizer nada". O poema "Psicanálise caseira" parece se referir diretamente a isto: "há coisas de sobra que não se dizem/ há coisas que sobram no que se diz/ nossa miséria é uma alegria de palavras?” (SISCAR, 2003, p.69).

Ao longo dos poemas de Marcos Siscar, temos momentos em que algo está efetivamente sendo "dito", como aqui. Ou seja, em que uma significação parece aglutinar ou organizar os elementos do poema. Como no caso deste "Psicanálise caseira", o sentido do poema depende de uma significação mais forte, há uma mensagem que sobressai e conduz a leitura. Entretanto, em sua poesia há de fato muita coisa que "sobra" no que se diz e "coisas de sobra que não se dizem" rondando os versos. Coisas que dão aos poemas muitas vezes um ar meio difícil ou, até mesmo, hermético. Assim como em relação à Ana Cristina, há leitores que consideram a poesia de Siscar difícil e, não raro, confundem-na com um excesso de hermetismo ou de erudição. O fato de Siscar, por exemplo, ser ligado ao estudo da filosofia, faz com que

\footnotetext{
${ }^{75}$ Poderíamos observar que o trabalho com o não-dito ou não-senso é mais intenso nos poemas reunidos em Metade da arte do que nos livros posteriores de Siscar, como $O$ roubo do silêncio (2006) e Interior via satélite (2010). Entretanto, não teremos como analisar essas diferenças nos limites deste estudo.
} 
alguns de afastem de sua poesia por achar que, para entendê-la, seria necessária alguma chave filosófica.

A constatação de ilhas de não-senso em sua poesia, no entanto, é algo que vai na contramão desta percepção, levando-nos à ideia de silêncios, vazios ou lapsos que pedem para permanecer sem nomeação ou explicação. O não-senso irromperia justamente aí, nesses momentos de impossibilidade de nomear, de designar ou significar. O não-senso irrompe e quebra a comunicabilidade do poema, rompe a função habitual da linguagem e força a emergência de sentidos, sempre múltiplos e não restringíveis à dimensão linguística. Vejamos esses poemas da série "Metade da arte" (2003):

\author{
diante de si estas palavras e não outras \\ a boca disse e dirá e não terá sido pouca \\ palavra sequer a sua não há conserto ou \\ festa apenas você isso muito me espanta \\ e o coração sem memória desperta \\ para o que não se deu ora tudo \\ que não se deu se pode dizer dizer não \\ se faz com fatos ah alegria da negação \\ todas as vezes que morri pergunte ao pó \\ o que direi da sua voz não sobra \\ nada senão a atenção do gesto o corte \\ um ícone da privação do fluxo enquanto \\ olhos inundados por humores de urina \\ virão romper o nosso pacto de silêncio \\ e então meus braços farão o nó da \\ proximidade aflita diga quantas vezes \\ sua boca me destilou delírios quantas \\ vezes um gemido nos salvou um mundo (p.8) \\ O que você quer me dizer me diga \\ na sua frente sou um puro espelho \\ um espelho só seu eu o aparo \\ pelos ombros me diga o que fazer \\ o que fazer para tirar a sua dor \\ como viver diante de sua dor não \\ me diga o que eu sou resposta \\ para a pergunta é sua voz inaudível \\ me diga o que sou o que lhe quero \\ como dividir a sua dor me diga \\ me abrace não me deixe agora vá (p.16)
}

Diversos procedimentos são responsáveis por esta sintaxe desconcertante nos poemas. O não-senso em Marcos Siscar também é cavado, como em Ana C., com o 
excesso de cortes, mas que se dá, como vemos, de outros modos. Há fragmentos colocados em fluxo, encadeados na corrente sintática. Siscar usa bastante dos enjambements, recurso da poesia tradicional que consistia em emendar um verso no outro, fazendo uma frase maior do que a métrica do verso, e portanto fazendo a frase continuar no verso seguinte. Embora aqui não tenhamos uma poesia metrificada, temos este recurso de fazer com que a frase seja interrompida pela quebra de linha e prossiga no verso seguinte. A continuidade da frase é então quebrada pela mudança de linha. E, ainda, ao mesmo tempo em que a frase é cortada, continuando no verso seguinte, o verso também é cortado e outra frase é iniciada no meio dele. Às vezes palavras acabam ficando soltas e orações parecem rompidas na metade, sem se concluir. E tem-se como resultado versos que sozinhos soam sem pé nem cabeça, como: "palavra sequer a sua não há conserto ou". É preciso ler mais de uma vez o poema para que se note que, no meio de uma aparente desconexão, há diversas significações que subsistem. Muitas delas falam sobre a própria poesia se fazendo, como por exemplo em: "da sua voz não sobra nada senão a atenção do gesto o corte, um ícone da privação do fluxo". É o próprio poema se referindo ao movimento que o constitui: a dinâmica entre o fluxo, sintático, rítmico, e o corte, que priva a fluência, que a estanca.

Mas o poema não pode simplesmente ser traduzido por mensagens ou significações. Há coisas que sobram no que se diz. Ele é a ciranda dessas sobras. E seu sentido depende dessas cirandas. Trata-se de um sentido que se cria nesta fronteira com o não-senso. A palavra ciranda, neste caso, não é casual. Um dos procedimentos bastante presentes nestes poemas de Siscar é o procedimento de repetição. Pode ser a repetição de palavras, de sonoridades, mas pode ser, ainda, a repetição de expressões inteiras ou orações, que são retomadas em loop, reiteradas, e parecem conferir ao poema um movimento em espiral. São cirandas descentradas, pois não temos repetições que se dão como na poesia tradicional, com o paralelismo ou o uso do refrão - casos em que temos um movimento de fato mais circular, como se, ao voltar o refrão, o poema girasse em torno de um eixo, voltasse para o mesmo ponto. Parece-me que em Siscar a repetição não tem como efeito a circularidade reiterativa, mas sim, algo mais próximo a um movimento em espirais. É interessante que um dos poemas descreve, justamente, este movimento: 
Não se diz voltar um rio se vai
com espirais de alga se devolvendo
não se diz ficar quando ascende
pela onda ao espírito do movimento
nunca as mesmas águas mas por revide
sempre remontando sua fonte
não se diz sugar do rio extrai-se
pela linha tensa o dom da completude
(as sanguessugas remontam pelo corpo
às veias abertas do rio de oiro)
ao rio se vai não se diz voltar
com seu sangue próprio ao que o reclama (p.85, grifos meus).

Então, ao repetir, não se volta para o mesmo ponto. Assim como a um rio "não se diz voltar" mas sempre ir, lembrando aqui a lição de Heráclito, já parte da sabedoria popular, de que não se entra duas vezes no mesmo rio, "nunca as mesmas águas", diz o poema. No artigo “A lição do rio" Celia Pedrosa (2004) ressalta justamente a constância da imagem do rio no poema de Siscar, enquanto a presença de um movimento de rio, de fluxo e refluxo, em sua escrita. E é importante notar que este "re", do refluxo, do repetir, não é índice de um retorno ao mesmo ponto, de um girar sobre o mesmo eixo. Há um eixo que se desloca. O eixo do poema muda de lugar. Aqui, o "não se diz" é um pequeno eixo que retorna (ver grifos) e, ao retornar, vem combinado a cada vez com um verbo diferente, até que retorna ao final, em outra posição - no final do verso ao invés de no início como nas ocorrências anteriores - com o mesmo verbo inicial que, não por acaso, é o "voltar". Ele volta modificado. O eixo do poema é, portanto, mutável, porque ele é muitos e também porque ele mesmo, ao retornar, é modificado. Este eixo mutante pode ser uma palavra, o "não", e depois uma expressão, "não devo", e em seguida ser outra palavra, "coisas", como no poema "Tudo é comum", no qual o papel rítmico deste eixo se faz bastante presente:

não não devo ser o único a apertar o passo na direção de coisas sem minúcia de coisas que não me olham de coisas sem rumo não não devo omitir que são nulas não devo ser o único a passar diante do próprio rosto fazer o ator de quem se crê dar alma à coisa mim uma pedra para o prumo tão sensível não serei mais que isto singular inespecífico se digo o insignificante e o dever de dizê-lo não serei o único a dizer e só suas mãos me calam suas orelhas me auscultam o peito 
você sorri me dizendo que tudo é comum (p.32).

Tem-se um som, um ritmo que conduz o poema. Uma batida, uma pulsação, um pulso. E é este pulso que, muitas vezes, salta nos poemas de Siscar: ele se autonomiza, ganha vida própria. Ele muitas vezes parece até mesmo embaçar os significados - já embaralhados - do poema. E então esses elementos repetidos, que criam pequenos ciclos sonoros, parecem valer por si, chamar a atenção para si próprios, como o refrão de uma cantiga que cantarolamos. Repetir o refrão não tem a função de significar algo na cantiga, mas apenas a de repetir por repetir, criando volume, fazendo-o valer por si, pela sua materialidade sonora. O que se tem é uma espécie de esvaziamento dos significados das palavras, como nas brincadeiras de criança em que se repete excessivamente uma palavra até o ponto de ela perder seu significado. Em uma entrevista, Siscar lembra-se do prefácio a seu livro Não se diz, em que o poeta Michel Déguy relaciona os volteios de sua escrita ao enigma que a habita:

No prefácio ao Não se diz, Déguy fala de perífrase. O poema faz rodeios, gira em torno do pote (tourner autour du pot), isto é, daquilo que se esquiva. Acho a ideia interessante. Mas, como você sugere, talvez o poema seja o pote, o fragmento recortado de algo que vai além dele e que ele apenas enxerga do ponto de vista de sua perplexidade. Se me fosse permitido a apropriação dessas duas ideias como minhas, eu diria que o poema é uma convivência conflituosa entre a perífrase e o recorte, e é isso que lhe permite manter o enigma, ao mesmo tempo que o elabora (SISCAR apud MALUFE, 2011, p.242).

O enigma é outro termo para se referir a isto que denominamos por não-dito ou “o que não se diz" ou, ainda, por silêncio. Este lapso que corta o poema e que permanece inominado, sem significação, sem nome, criando um não-senso na superfície do poema é também o enigma. Nesta fala de Siscar (p.243) transparece sua necessidade de manter o enigma enquanto enigma: "Onde o enigma é decifrado, não há mais enigma", diz em outro momento. O enigma é um artifício construído pelo texto e, ao mesmo tempo, é o espaço vazio, o silêncio que permite o trânsito do poema com o real, do real com o poema. Ele é um silêncio sem chave prévia, daí a vertigem:

Silêncio é uma palavra que uso para dizer uma vertigem, ou um enigma. $O$ silêncio é digno de poesia quando, num determinado momento, ele se apresenta destituído de sentido, de intencionalidade, 
de historicidade - única maneira de apresentar o mundo como se fosse pela primeira vez. Há vertigem poética quando o silêncio se apresenta enquanto tal (SISCAR apud MALUFE, p.243-244).

É um pouco difícil para nós, muitas vezes, nos depararmos com um vazio de significação, com um lapso, e não procurarmos preenchê-lo com palavras, explicações, referências. Daí a dificuldade da vertigem poética: viver "o silêncio que se apresenta enquanto tal". Temos uma espécie de vício da significação, vício enraizado por demais em nossa cultura ocidental. O que esses dois casos, o de Siscar e o de Ana C. nos ensinam, portanto, é outro tipo de escuta para as palavras. Uma escuta que conta com o silêncio para se fazer. O que está em jogo é, em ambos, o que o poema pode fornecer de experiência de abalo, de ruptura de modos habituais de sentir, de ouvir, de ler, de pensar. E este abalo não é de ordem primeiramente intelectual ou racional. Ele precisa de fato acontecer no corpo de quem lê: o sentido se dá em um terreno que antecede as elaborações mais bem formadas e organizadas da ordem da significação. Ele se dá em camadas sub-representativas. É preciso um lapso, um corte, uma rasteira, um não-senso. De modo que, sem a disponibilidade para o inominável este abalo pode passar, de fato, desapercebido.

\section{REFERÊNCIAS}

BAUDELAIRE, C. Les fleurs du mal. Paris: Garnier-Flammarion, 1964.

BOSI, V. Artes plásticas e poesia nos anos 70 no Brasil. Atas do VI Congresso Nacional da Associação Portuguesa de Literatura Comparada / X Colóquio de Outono Comemorativo das Vanguardas [2009/2010]. Minho: Universidade do Minho, 2010.

CESAR, A. C. A teus pés. São Paulo: Ática, 1999a. Crítica e tradução. São Paulo: Ática, 1999b. Inéditos e dispersos. São Paulo: Ática, 1999c.

DELEUZE, G. Logique du sens. Paris: Minuit, 1969. Différence et répétition. Paris: PUF, 1968.

HOLlANDA, H. B. de; FREITAS FILHO, A. (Org.). Ana Cristina Cesar: Correspondência incompleta. Rio de Janeiro: Aeroplano, 1999.

MALUFE, A. C. Poéticas da imanência: Ana Cristina Cesar e Marcos Siscar. Rio de Janeiro: 7Letras; São Paulo: FAPESP, 2011. 
Territórios dispersos: a poética de Ana Cristina Cesar. São Paulo: Annablume/FAPESP, 2006.

MORICONI, I. Ana Cristina Cesar, o sangue de uma poeta. Rio de Janeiro: Relume Dumará, 1996.

PAZ, O. Los hijos del limo. Barcelona: Seix Barral, 1974.

PEDROSA, C. Versos que correm entre a margem e o fluxo, a linha e o corte. Jornal do Brasil, Caderno Idéias, Rio de Janeiro, 30 de outubro de 2004, p.4.

SISCAR, M. Interior via satélite. Cotia, SP: Ateliê, 2010.

O roubo do silêncio. Rio de Janeiro: 7Letras, 2006.

. Metade da arte. São Paulo: Cosac Naify; Rio de Janeiro: 7Letras, 2003.

SÜSSEKIND, F. Até segunda ordem não me risque nada. Rio de Janeiro: 7Letras, 1995.

TZARA, T. Dada est tatou. Tout est dada. Paris: Flammarion, 1996.

Artigo recebido em 30/03/2011

Aceito para publicação em 07/07/2011 